\title{
Application of Plackett-Burman Design for Screening of Factors Affecting Pitavastatin Nanoparticle Formulation Development
}

\author{
Vinodkumar D. Ramani ${ }^{1}$, Girish K. Jani ${ }^{2}$, Girish U. Sailor ${ }^{3}$ \\ ${ }^{1}$ Department of Pharmacy, Gujarat Technological University, Ahmedabad, India \\ ${ }^{2}$ Department of Pharmacy, K.B. Raval College of Pharmacy, Gandhinagar, India \\ ${ }^{3}$ Bhagwan Mahavir College of Pharmacy, Bhagwan Mahavir University, Surat, India
}

Corresponding author: Vinodkumar D. Ramani, Department of Pharmacy, Gujarat Technological University, Ahmedabad, India; E-mail: vinod. ramani01@gmail.com

Received: 1 Sep $2020 \diamond$ Accepted: 30 Sep $2020 \diamond$ Published: 31 Oct 2021

Citation: Ramani VD, Jani GK, Sailor GU. Application of Plackett-Burman design for screening of factors affecting pitavastatin nanoparticle formulation development. Folia Med (Plovdiv) 2021;63(5):775-85. doi: 10.3897/folmed.63.e58174.

\begin{abstract}
Introduction: Nanoparticle formulation of pitavastatin calcium is a potential alternative to solve the solubility related problem. However, the formulation of nanoparticle involves various parameters that affect product quality. Plackett-Burman design could facilitate an economical experimental plan that focuses on determining the relative significance of many.
\end{abstract}

Aim: The objective of this study was to screen the variables which could significantly affect the pitavastatin nanoparticle formulation.

Materials and methods: The pitavastatin nanoparticles were formulated by preparing nanosuspension using the emulsion solvent evaporation technique followed by freeze-drying. A Plackett-Burman screening design methodology was employed in which seven factors at two levels were tested at 12 runs to study the effect of formulation and process variables on particle size and polydispersity index of nanoparticles. The surface morphology and crystalline nature of nanoparticle were also evaluated.

Results: The particle size and polydispersity index of nanosuspension was found in the range of 113.1 to $768.5 \mathrm{~nm}$ and 0.068 to 0.508 , respectively. Statistical analysis of various variables revealed that stabilizer concentration, injection flow rate, and stirring rate were the most influential factors affecting the particle size and polydispersity index of the formulation. X-ray diffraction (XRD) and scanning electron microscopy (SEM) study suggested the amorphous nature of nanoparticles.

Conclusions: This study concluded that the Plackett-Burman design was an efficient tool for screening the process and formulation variables affecting the properties of pitavastatin nanoparticles and also for the identification of the most prominent factor.

\section{Keywords}

freeze drying, nanoparticles, pitavastatin, Plackett-Burman design, screening design

\section{INTRODUCTION}

Cardiovascular diseases remain the leading cause of death in older adults, accounting for $60 \%$ of deaths in those aged 85 years or older which can be controlled by treating the major risk factors. ${ }^{1,2}$ Hyperlipidemia is the most important risk factor for atherosclerosis, which is a well-documented cause of cardiovascular disease. ${ }^{3}$ It is manifested by an abnormal increase in cholesterol, triglycerides, and lipoproteins. Treating these risk factors, hyperlipidemia has been 
proven beneficial in reducing the mortalities and morbidities of cardiovascular disease.

Statins, competitive inhibitors of HMG-CoA reductase, are the most widely used drugs in lowering blood cholesterol for pharmaceutical prevention of cardiovascular disease. ${ }^{4,5}$ Pitavastatin calcium (PTV) is a new generation statin that has greater efficacy in reducing the low-density lipoprotein-cholesterol (LDL-C) and change in other lipoprotein compared to other statins. However, its therapeutic efficacy is limited due to its poor aqueous solubility. ${ }^{6}$ Moreover, the presence of food decreases the $\mathrm{C}_{\max }$ by $38.6 \%$ and AUC by $5 \%$ of pitavastatin. Therefore, long-term treatments and high doses are required to reach optimal plasma concentrations, but this almost inevitably invites toxic sideeffects such as myopathy and rhabdomyolysis. ${ }^{7}$ Efficacy of PTV can be enhanced by improving its aqueous solubility and dissolution. Different strategies have been utilized to improve the aqueous solubility and dissolution rate of PTV, such as the preparation of solid dispersions ${ }^{8}$, co-crystal ${ }^{9}$, inclusion complexes ${ }^{10}$, self-microemulsifying drug delivery system (SMEDDS) ${ }^{11}$, etc. In recent years, nanoparticle engineering technique has gained importance as a promising approach for the enhancement of drug solubility. The nanoparticle is a potential alternative to solve the issue associated with poor water as well as lipid-soluble drugs due to its distinct physicochemical properties and submicron size particle.

The emulsion solvent evaporation technique that has been reported for the formulation of nanosuspension is a relatively simple and easy-to-scale-up process. ${ }^{12}$ However, the emulsion solvent evaporation process involves various parameters that affect product quality. ${ }^{13}$

\section{AIM}

Thus, this study aimed to evaluate these process and formulation factors using Plackett-Burman design and to screen the critical parameters that influence nanoparticle characteristics including particle size and polydispersity index.

\section{MATERIALS AND METHODS}

\section{Materials}

Pitavastatin calcium was obtained as a gift sample from Zydus Cadila, Ahmedabad. Pluronic ${ }^{\circledR}$ P85 was purchased from BASF Corporation. D-a-tocopherol polyethylene glycol 1000 succinate $\left(\right.$ TPGS $^{\circledR}$-1000) purchased from Sigma Aldrich. Methanol $(\mathrm{MeOH})$ and acetone (ACE) were purchased from Loba Chemie Pvt. Ltd., Mumbai. Deionized water was produced in-house using EMD Millipore Direct-Q 3 System, Millipore Corporation, Bedford, USA.

\section{Methods}

\section{Preparation of pitavastatin calcium nanoparticles}

The PTV nanoparticle suspension was prepared using the emulsion solvent evaporation technique. In this method, the organic phase was prepared by dissolving the drug in the organic solvent. The aqueous phase was prepared by dissolving stabilizing agent in deionized water. The aqueous phase was stirred in $250 \mathrm{~mL}$ beaker at a specific stirring rate and maintained at fixed temperature using magnetic stirrer equipped with hot plate (RCT Basic, IKA India Pvt. Ltd., Bengaluru). Then, the organic phase was poured at precise rate in the aqueous phase using a syringe pump (Infusa 101P, Devay Medical Technologies, Vadodara). The obtained suspension was continuously stirred at same temperature till complete evaporation of organic phase. Finally, nanosuspension was placed at $-80^{\circ} \mathrm{C}$ (Deep Freezer, SU105UE, Undercounter, Stirling Ultracold, USA) for $12 \mathrm{hr}$ and freeze dried (MSW-137, Macro scientific works, Delhi) at $-40^{\circ} \mathrm{C}$ for 48 hours. The obtained nanoparticles were kept in a desiccator at $4^{\circ} \mathrm{C}$ until further analysis.

\section{Experimental design (Plackett-Burman design)}

The prior study was reviewed to identify the formulation and process variables for current preparation method. The average particle size and polydispersity index (PDI) were considered as critical properties of nanoparticle since these properties are expected to influence its clinical efficacy. Four formulation variables and three process variables (total seven variables) that affect the properties of nanoparticle were specified and included in the present study.

In the present study, we have used the Plackett-Burman design (PBD) for development of PTV nanoparticle. Seven factors at two levels were tested at 12 runs to study the effect of formulation and process variables on particle size and PDI. High and low levels of factors were decided according to previous study and review of data. Design Expert $^{\circledR}$ software (V-10.0.1.0, State-Ease Inc., Minneapolis, MN, USA) was used to generate and randomize the design matrix which is then statistically analyzed. The factor coefficients and significance of the model were evaluated through multiple regression analysis and ANOVA.

\section{Evaluation of nanoparticles}

\section{Particle size and polydispersity index}

The particle size and particle size distribution (polydispersity index) of the prepared formulations were determined by dynamic light scattering technique using Zetatrac (Microtrac Inc., USA). The analysis was carried out using deionized water as disperse media at $25^{\circ} \mathrm{C} \pm 1^{\circ} \mathrm{C} . .^{14,15}$ 


\section{Scanning electron microscopy}

The surface morphology of prepared nanoparticles was observed under scanning electron microscope (JSM-6010LA; JEOL, Tokyo, Japan). The samples were gold plated with sputter coater, placed on aluminum plates, and observed at an acceleration voltage of $15 \mathrm{kV}$.

\section{Powder X-ray diffraction study}

To evaluate the crystalline state of prepared formulation, powder X-ray diffraction (XRD) study was performed. XRD pattern was recorded using X-ray diffractometer (Xpert Pro MPD, Powder PAN analytical system, Almelo, Netherland) with $\mathrm{Cu} \mathrm{Ka}$ radiation generated at $40 \mathrm{~mA}$, $35 \mathrm{kV}$, and $1.5405 \AA$ wavelength using Xcelerator detector with diffracted beam monochromator.

\section{RESULTS AND DISCUSSION}

\section{Selection of variables}

Pitavastatin nanoparticles were formulated by preparing nanosuspension using emulsion solvent evaporation technique followed by freeze drying. The solvent stabilizer pair is crucial to obtain submicron particles. In the preliminary work, acetone and methanol were found to be promising solvents to prepare an organic phase because of its highest capacity to solubilize pitavastatin. The effects of different stabilizers like Pluronic P85, TPGS-1000, PVP K30, Poloxamer 188, SLS, and Tween 80 were evaluated. The Pluronic P85 and TPGS-1000 were found to be promising stabilizer among all the stabilizers as it produces smallest nanoparticles with narrow particle size distribution (data not shown). It has been found from the preliminary studies that the nanoparticle's quality was affected by stabilizer concentration, organic phase volume, stirring rate, temperature of aqueous phase, and injection flow rate. The details of selected variables are presented in Table 1. The process and formulation factors were screened using Plackett-Burman $(\mathrm{PB})$ design to find the few significant factors from a list of many potential ones.

\section{Screening of variables using Plackett- Burman design}

Plackett-Burman designs are very efficient screening designs when only main effects are of interest. With the help of this design, the construction of very economical designs with the run number a multiple of four (rather than a power of 2). ${ }^{23} \mathrm{~PB}$ designs are used for screening experiments because, in a PB design, main effects are, in general, heavily confounded with two-factor interactions. The PB design in 12 runs, for example, may be used for an experiment containing up to 11 factors. In this work 7 -factor, 12-run Plackett-Burman screening design was constructed using Design Expert ${ }^{\circledR}$ software (V-10.0.1.0, State-Ease Inc.,
Minneapolis, MN, USA).

Independent variables selected were stabilizer type $\left(\mathrm{X}_{1}\right)$, stabilizer concentration $\left(\mathrm{X}_{2}\right)$, organic phase type $\left(\mathrm{X}_{3}\right)$, organic phase volume $\left(\mathrm{X}_{4}\right)$, stirring rate $\left(\mathrm{X}_{5}\right)$, temperature of aqueous phase $\left(\mathrm{X}_{6}\right)$, and injection flow rate $\left(\mathrm{X}_{7}\right)$. The partial size (PS) and polydispersity index (PDI) were selected as dependent variables. The parameter level selection was based on preliminary studies and literature survey. The Plackett-Burman screening design setup and design output matrix with results are summarized in Tables 2, 3, respectively. The polynomial equation to determine the effect of the factors on the response is given below:

$$
\mathrm{Y}=\mathrm{b}_{0}+\mathrm{b}_{1} \mathrm{X}_{1}+\mathrm{b}_{2} \mathrm{X}_{2}+\mathrm{b}_{3} \mathrm{X}_{3}+\mathrm{b}_{4} \mathrm{X}_{4}+\mathrm{b}_{5} \mathrm{X}_{5}+\mathrm{b}_{6} \mathrm{X}_{6}+\mathrm{b}_{7} \mathrm{X}_{7}
$$

where, $\mathrm{Y}$ is the dependent variable while $\mathrm{b}_{0}$ is the intercept, $b_{i}\left(b_{1}\right.$ to $\left.b_{7}\right)$ represents the regression coefficient for the first order polynomial and $\mathrm{X}_{\mathrm{i}}$ represents the levels of independent formulation variables. The magnitude and direction of factor coefficients in the above equation explain the nature of the effect of factors on the response Y.

\section{Effect analysis of variables on particle size $\left(Y_{1}\right)$}

The particle size of all prepared batches was in ranges from 113.1 to $768.5 \mathrm{~nm}$ (Table 3). The reasonable impacts of independent variables were observed in all the cases while performing the experiments in random order. The regression output for particle size $\left(\mathrm{Y}_{1}\right)$ is presented in Table 4. The $\mathrm{R}^{2}$ value was 0.9980 indicating a good fit. The analysis of variance (ANOVA) revealed a statistical difference between the batches. A regression coefficient is said to be significant if the $p$-value is less than 0.05 (95\% CI). From the result (Table 4), it is evident that stabilizer concentration $\left(p=5.11 \times 10^{-6}\right)$, stirring rate $\left(p=2.55 \times 10^{-5}\right)$, and injection flow rate $\left(p=5.28 \times 10^{-5}\right)$ significantly affect the particle size which is again confirmed by respective \% contribution value (Table 4) and Pareto chart (Fig. 1). The term effect plot (Fig. 2) shows the factor's main effect and the effect of significant factor on the particle size. When the smaller particle size is desired within selected factor range, factors $\mathrm{X}_{2}$ and $\mathrm{X}_{5}$ have negative coefficients which indicate that decreasing the factor value increases the response which means that decreasing stabilizer concentration and stirring rate increases the particle size of nanoparticles. Contrarily, factor $\mathrm{X}_{7}$ has positive coefficients which indicate that increasing the factor value increases the response, which means that increasing the injection flow rate increases the particle size of nanoparticles. Besides that, the coefficient of factor $\mathrm{X}_{2}$ is higher as compared to that of $\mathrm{X}_{5}$ and $\mathrm{X}_{7}$, which shows that factor $\mathrm{X}_{2}$ has more significant effect on particle size of nanoparticles compared to that of $\mathrm{X}_{5}$ and $\mathrm{X}_{7}$.

The stabilizer type, TPGS-1000 favours the smaller particle size compared to that of Pluronic P85. This may be owing to a higher value of critical micellar concentration (CMC) of TPGS-1000. The organic phase, acetone favours the smaller particle size compared to that of 
Table 1. Selection of independent variables

\begin{tabular}{|c|c|c|c|}
\hline $\begin{array}{l}\text { Sr. } \\
\text { No. }\end{array}$ & $\begin{array}{l}\text { Independent } \\
\text { Variables }\end{array}$ & Range & Reason for selection \\
\hline \multicolumn{4}{|c|}{ Formulation variables } \\
\hline 1 & Organic phase type & $\begin{array}{l}\text { Acetone and } \\
\text { methanol }\end{array}$ & $\begin{array}{l}\text { A selected solvent should be able to dissolve the drug and miscible with aqueous phase } \\
\text { over the concentration range. Changing the solvent not only alters the supersaturation } \\
\text { conditions, but also affects viscosity and surface tension, and consequently changes the } \\
\text { nucleation rate. }{ }^{16}\end{array}$ \\
\hline 2 & $\begin{array}{l}\text { Organic phase } \\
\text { volume }\end{array}$ & $6-12 \mathrm{~mL}$ & $\begin{array}{l}\text { The organic phase volume alters the drug concentration which could affect the particle } \\
\text { property. }\end{array}$ \\
\hline 3 & Stabilizer type & $\begin{array}{l}\text { Pluronic P85 } \\
\text { and TPGS } \\
-1000\end{array}$ & $\begin{array}{l}\text { It stabilizes the formed nanoparticle and stops further growth and aggregation by the } \\
\text { free energy reduction, steric hindrance, and electrostatic stabilization. }{ }^{17} \text { Additionally, } \\
\text { selected stabilizers have some permeation enhancing effect through P-gp inhibition. }{ }^{18}\end{array}$ \\
\hline 4 & $\begin{array}{l}\text { Stabilizer concen- } \\
\text { tration }\end{array}$ & $\begin{array}{l}0.01-0.04 \% \\
\mathrm{w} / \mathrm{v}\end{array}$ & $\begin{array}{l}\text { A low concentration of stabilizer may not be sufficient and promotes discreet coating of } \\
\text { nanoparticle while higher concentration may promote aggregation through depletion } \\
\text { flocculation mechanism. }{ }^{19}\end{array}$ \\
\hline \multicolumn{4}{|c|}{ Process variables } \\
\hline 5 & Stirring speed & $\begin{array}{l}500-2500 \\
\text { RPM }\end{array}$ & $\begin{array}{l}\text { The mechanical stirring helps to promote even degree of supersaturation and also in- } \\
\text { tensifies micro-mixing which increases the rate of diffusions and mass transfer between } \\
\text { multiphase systems. This favours the generation of small particles due to rapid and } \\
\text { uniform nucleation. } .^{20}\end{array}$ \\
\hline 6 & $\begin{array}{l}\text { Temperature of } \\
\text { aqueous phase }\end{array}$ & $30-65^{\circ} \mathrm{C}$ & $\begin{array}{l}\text { The temperature affects the equilibrium saturation, supersaturation concentration, } \\
\text { diffusion rate, and viscosity of the system. Additionally, the change in the temperature } \\
\text { during nucleation also affects the physical property of nanoparticle. }{ }^{20,21}\end{array}$ \\
\hline 7 & $\begin{array}{l}\text { Injection flow rate } \\
\text { (rate of organic } \\
\text { phase addition) }\end{array}$ & $\begin{array}{l}0.5-1.5 \mathrm{~mL} / \\
\min \end{array}$ & $\begin{array}{l}\text { The injection flow rate affects the extent of mixing per unit time which strongly influ- } \\
\text { ences the particle size distribution. }{ }^{22} \text { Furthermore, it also alters the degree of super- } \\
\text { saturation and therefore strongly influences the nucleation rate and particle growth } \\
\text { kinetics. }{ }^{16}\end{array}$ \\
\hline \multicolumn{4}{|c|}{ Variables kept constant } \\
\hline 8 & Drug quantity & $100 \mathrm{mg}$ & $\begin{array}{l}\text { The drug quantity was kept constant }(100 \mathrm{mg}) \text { for all batches of nanosuspension so that } \\
\text { comparative observation can be drawn for each independent factor. }\end{array}$ \\
\hline 9 & $\begin{array}{l}\text { Final volume of } \\
\text { nanosuspension } \\
\text { (aqueous phase }+ \\
\text { organic phase) }\end{array}$ & $50 \mathrm{~mL}$ & $\begin{array}{l}\text { In this study, the final volume of nanosuspension was kept constant }(50 \mathrm{~mL}) \text { and } \\
\text { volume of organic phase was varied thus volume of aqueous phase and its ratio to the } \\
\text { organic phase gets varied by default. It allows us to indirect estimation of the effect of } \\
\text { ratio (organic phase to aqueous phase) on the physical properties of nanoparticles. }\end{array}$ \\
\hline
\end{tabular}

Table 2. Plackett-Burman screening design setup

\begin{tabular}{llll}
\hline Factor Code & Factor Name & $\begin{array}{l}\text { Level } \\
\text { Low }(-\mathbf{1})\end{array}$ & High $(+\mathbf{1})$ \\
\hline Independent Factors & & & TPGS-1000 \\
$\mathrm{X}_{1}$ & Stabilizer type & Pluronic P85 & 0.04 \\
$\mathrm{X}_{2}$ & Stabilizer concentration $(\% \mathrm{w} / \mathrm{v})$ & 0.01 & $\mathrm{MeOH}$ \\
$\mathrm{X}_{3}$ & Organic phase type & ACE & 12 \\
$\mathrm{X}_{4}$ & Organic phase volume $(\mathrm{mL})$ & 6 & 2500 \\
$\mathrm{X}_{5}$ & Stirring rate (RPM) & 500 & 65 \\
$\mathrm{X}_{6}$ & Temperature of aqueous phase $\left({ }^{\circ} \mathrm{C}\right)$ & 30 & 1.5 \\
$\mathrm{X}_{7}$ & Injection flow rate $(\mathrm{mL} / \mathrm{min})$ & 0.5 & \\
\hline Dependent Factor & & & \\
$\mathrm{Y}_{1}$ & Particle size (nm) & & \\
$\mathrm{Y}_{2}$ & Polydispersity Index & & \\
\hline
\end{tabular}

For all batches: The drug quantity was $100 \mathrm{mg}$, DM water was used as an aqueous phase and the total volume of nanosuspension was 50 $\mathrm{mL}$. The nanoparticles were prepared using emulsion-solvent diffusion technique followed by freeze drying. 
Table 3. Plackett-Burman screening design output matrix with results

\begin{tabular}{|c|c|c|c|c|c|c|c|c|c|}
\hline \multirow{4}{*}{$\begin{array}{l}\text { Batch } \\
\text { Code }\end{array}$} & \multicolumn{7}{|c|}{ Independent variables } & \multicolumn{2}{|c|}{ Dependent variables } \\
\hline & \multirow[t]{2}{*}{ Stabilizer type } & $\begin{array}{l}\text { Stabilizer } \\
\text { concen- } \\
\text { tration }\end{array}$ & $\begin{array}{l}\text { Organic } \\
\text { phase }\end{array}$ & $\begin{array}{l}\text { Organic } \\
\text { phase } \\
\text { volume }\end{array}$ & $\begin{array}{l}\text { Stirring } \\
\text { rate }\end{array}$ & $\begin{array}{l}\text { Temperature } \\
\text { of aqueous } \\
\text { phase }\end{array}$ & $\begin{array}{l}\text { Injection } \\
\text { flow rate }\end{array}$ & PS & PDI \\
\hline & & $\% \mathbf{w} / \mathbf{v}$ & Type & $\mathbf{m L}$ & RPM & ${ }^{\circ} \mathrm{C}$ & $\mathrm{mL} / \mathrm{min}$ & nm & \\
\hline & $\mathrm{X}_{1}$ & $\mathrm{X}_{2}$ & $\mathbf{X}_{3}$ & $\mathrm{X}_{4}$ & $\mathrm{X}_{5}$ & $\mathrm{X}_{6}$ & $\mathrm{X}_{7}$ & $\mathrm{Y}_{1}$ & $\mathrm{Y}_{2}$ \\
\hline PNS1 & TPGS-1000 & 0.01 & $\mathrm{MeOH}$ & 12 & 500 & 65 & 1.5 & 743.4 & 0.453 \\
\hline PNS2 & Pluronic P85 & 0.01 & $\mathrm{MeOH}$ & 6 & 2500 & 65 & 0.5 & 503.2 & 0.443 \\
\hline PNS3 & Pluronic P85 & 0.04 & $\mathrm{MeOH}$ & 6 & 2500 & 65 & 1.5 & 390.9 & 0.402 \\
\hline PNS4 & Pluronic P85 & 0.04 & $\mathrm{MeOH}$ & 12 & 500 & 30 & 0.5 & 390.8 & 0.354 \\
\hline PNS5 & Pluronic P85 & 0.04 & $\mathrm{ACE}$ & 12 & 2500 & 30 & 1.5 & 305.3 & 0.319 \\
\hline PNS6 & TPGS-1000 & 0.04 & ACE & 6 & 500 & 65 & 0.5 & 324.3 & 0.226 \\
\hline PNS7 & TPGS-1000 & 0.01 & ACE & 6 & 2500 & 30 & 1.5 & 576.4 & 0.439 \\
\hline PNS8 & Pluronic P85 & 0.01 & $\mathrm{ACE}$ & 12 & 500 & 65 & 1.5 & 768.5 & 0.55 \\
\hline PNS9 & TPGS-1000 & 0.01 & $\mathrm{MeOH}$ & 12 & 2500 & 30 & 0.5 & 450.7 & 0.305 \\
\hline PNS10 & TPGS-1000 & 0.04 & ACE & 12 & 2500 & 65 & 0.5 & 113.1 & 0.068 \\
\hline PNS11 & Pluronic P85 & 0.01 & ACE & 6 & 500 & 30 & 0.5 & 647.2 & 0.508 \\
\hline PNS12 & TPGS - 1000 & 0.04 & $\mathrm{MeOH}$ & 6 & 500 & 30 & 1.5 & 545.6 & 0.435 \\
\hline
\end{tabular}

PS: particle size; PDI: polydispersity index; PNS: pitavastatin nanoparticle screening batch; TPGS-1000: D- $\alpha$-tocopherol polyethylene glycol 1000 succinate; MeOH: methanol; ACE: acetone; RPM: revolution per minute

Table 4. Regression analysis for particle size $\left(\mathrm{Y}_{1}\right)$

\begin{tabular}{|c|c|c|c|}
\hline \multirow[b]{2}{*}{ Independent variables } & \multicolumn{3}{|c|}{ Particle size $\left(\mathrm{Y}_{1}\right)$} \\
\hline & Coefficient & $P$-Value & $\begin{array}{l}\% \\
\text { Contribution }\end{array}$ \\
\hline Intercept & 480.03 & $<0.0001$ & - \\
\hline $\mathrm{X}_{1}$ - Stabilizer type & -21.12 & 0.0068 & 1.33 \\
\hline $\mathrm{X}_{2}$ - Stabilizer concentration & -134.87 & $<0.0001$ & 54.47 \\
\hline $\mathrm{X}_{3}$ - Organic phase type & 24.23 & 0.0041 & 1.75 \\
\hline $\mathrm{X}_{4}$ - Organic phase volume & -17.9 & 0.0120 & 0.95 \\
\hline $\mathrm{X}_{5}-$ Stirring rate & -90.1 & $<0.0001$ & 24.31 \\
\hline $\mathrm{X}_{6}$ - Temperature of aqueous phase & -6.13 & 0.2093 & 0.11 \\
\hline $\mathrm{X}_{7}$ - Injection flow rate & 74.98 & $<0.0001$ & 16.83 \\
\hline
\end{tabular}

methanol. This may be due to higher saturation solubility of PTV in acetone. Higher saturation solubility generates the profound driving force for the formation of particles during the process by unbalancing molecular interactions between organic phase, solute, and aqueous phase. ${ }^{19}$ Additionally, the results show that higher volume of organic phase $(12 \mathrm{~mL})$ slightly favours (\% contribution is 0.95 ) smaller particle size associated, maybe because it further decreases the drug concentration in organic phase. The effect of aqueous phase temperature $\left(\mathrm{X}_{6}\right)$ was found to be insignificant $(p>0.05)$ with a negative coefficient.

\section{Effect analysis of variables on polydispersity index (Y2)}

Results of the polydispersity index (PDI) for all batches of Plackett-Burman screening design are given in Table 3. Table 5 shows the regression analysis output for PDI. The $\mathrm{R}^{2}$ value was 0.9947 indicating a good fit. The analysis of variance (ANOVA) revealed a statistical difference between the batches. A regression coefficient is said to be significant if the $p$-value is less than 0.05 (95\% CI).

From the result (Table 5), it is evident that stabilizer con- 
V. Ramani et al

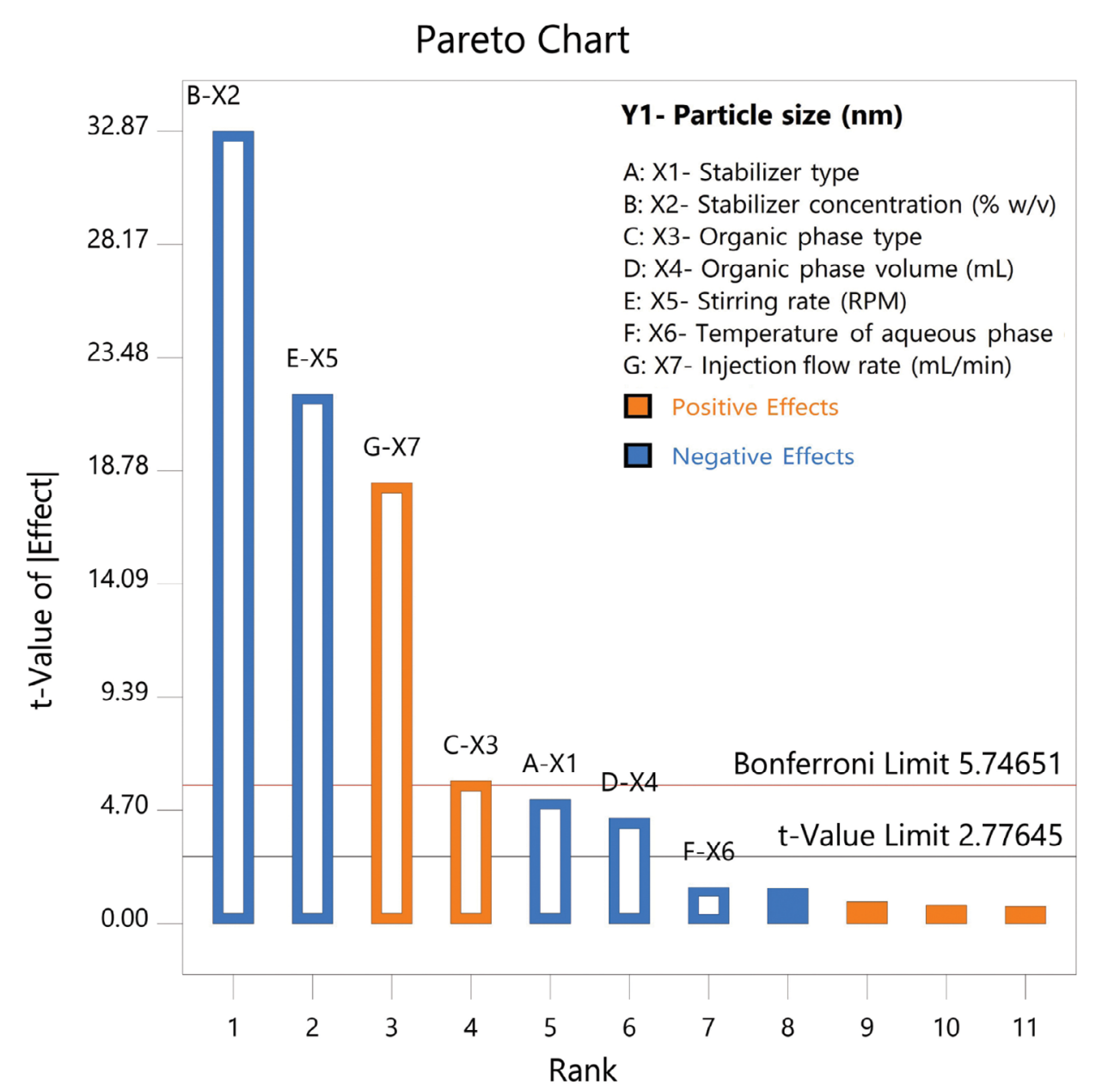

Figure 1. Pareto chart for particle size $\left(\mathrm{Y}_{1}\right)$.

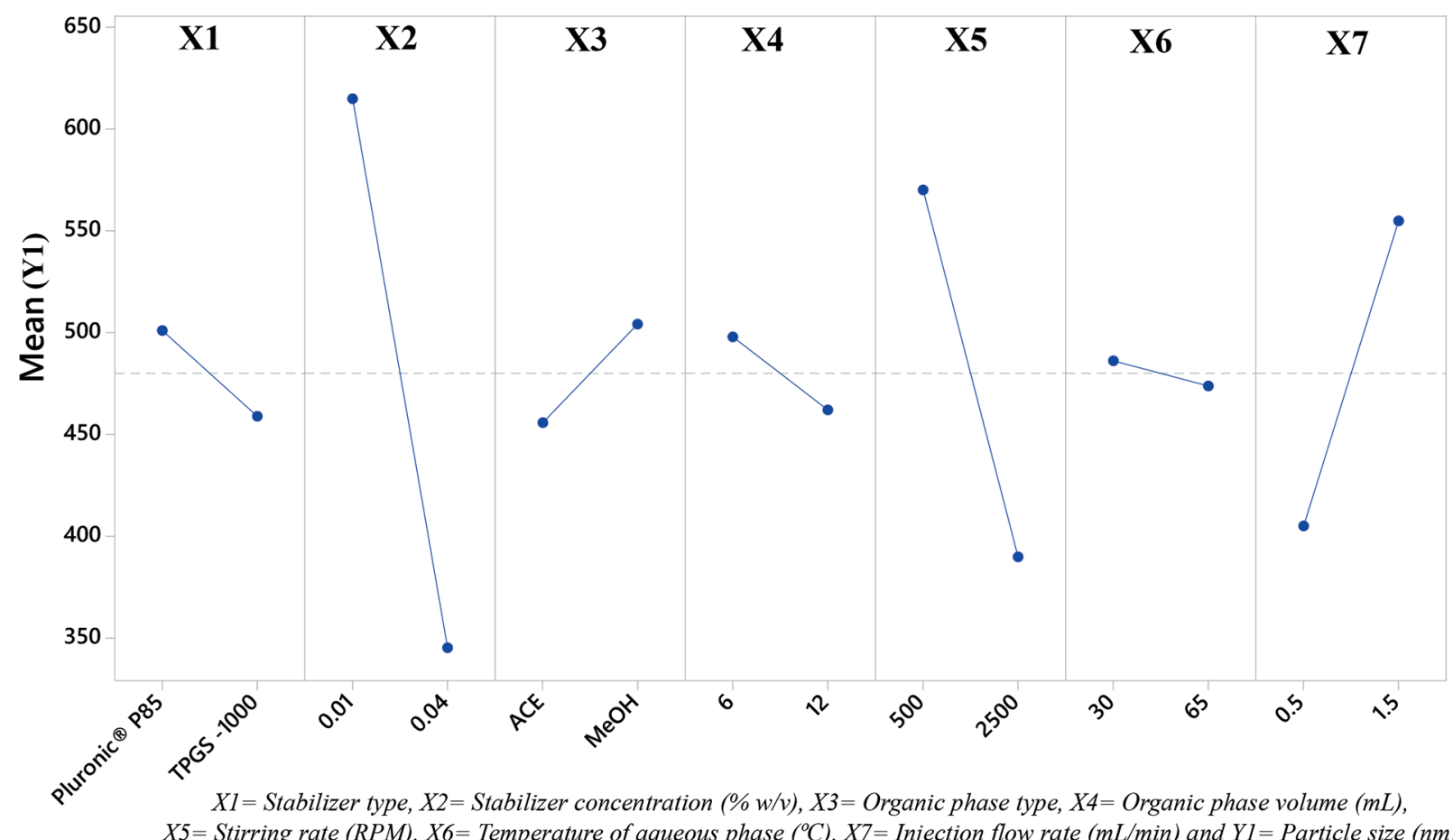

Figure 2. Term effect plot for particle size $\left(\mathrm{Y}_{1}\right)$. 
Table 5. Regression analysis for polydispersity index $\left(\mathrm{Y}_{2}\right)$

\begin{tabular}{llll}
\hline & \multicolumn{2}{c}{ Polydispersity index $\left(\mathrm{Y}_{2}\right)$} \\
\cline { 2 - 4 } Independent variables & Coefficient & $\boldsymbol{P}$-Value & \% \\
\hline Intercept & 0.3752 & 0.0002 & - \\
$\mathrm{X}_{1}$ - Stabilizer type & -0.0542 & 0.0003 & 18.30 \\
$\mathrm{X}_{2}$ - Stabilizer concentration & -0.0745 & $<0.0001$ & 34.62 \\
$\mathrm{X}_{3}$ - Organic phase type & 0.0235 & 0.0071 & 3.44 \\
$\mathrm{X}_{4}$ - Organic phase volume & -0.0337 & 0.0019 & 7.07 \\
$\mathrm{X}_{5}$ - Stirring rate & -0.0458 & 0.0006 & 13.10 \\
$\mathrm{X}_{6}$ - Temperature of aqueous phase & -0.0182 & 0.0172 & 2.05 \\
$\mathrm{X}_{7}$ - Injection flow rate & 0.0578 & 0.0002 & 20.86 \\
\hline
\end{tabular}

centration $\left(p=8.71 \times 10^{-5}\right)$, stirring rate $(p=0.0006)$, and injection flow rate $(p=0.0002)$ significantly affect the particle size which is again confirmed by respective $\%$ contribution value (Table 5), and Pareto chart (Fig. 3). The term effect plot (Fig. 4) shows the factor's main effect and the effect of significant factor on the particle size. When the lower PDI is desired within selected factor range, factors $\mathrm{X}_{2}$ and $\mathrm{X}_{5}$ have negative coefficients which indicate that decreasing the factor value increases the response which means that decreasing stabilizer concentration and stirring rate increases the PDI of nanoparticles. Contrarily, factor $\mathrm{X}_{7}$ has positive coefficients which indicate that increasing the factor value increases the response which means that increasing the injection flow rate increases the particle size of nanoparticles. Besides that, the coefficient of factor $\mathrm{X}_{2}$ is higher as compared to that of $\mathrm{X}_{5}$ and $\mathrm{X}_{7}$, which shows that factor $\mathrm{X}_{2}$ has more significant effect on particle size of nanoparticles compared to that of $\mathrm{X}_{5}$ and $\mathrm{X}_{7}$. During the emulsion solvent evaporation, high energy surfaces are generated which leads to aggregation or particle growth. Nevertheless, the existence of stabilizers that instinctively conceal the freshly generated high energy surface consequences in the decrease of surface energy and so enthalpy of system and therefore reduces uneven particle growth owing to steric stabiliza-

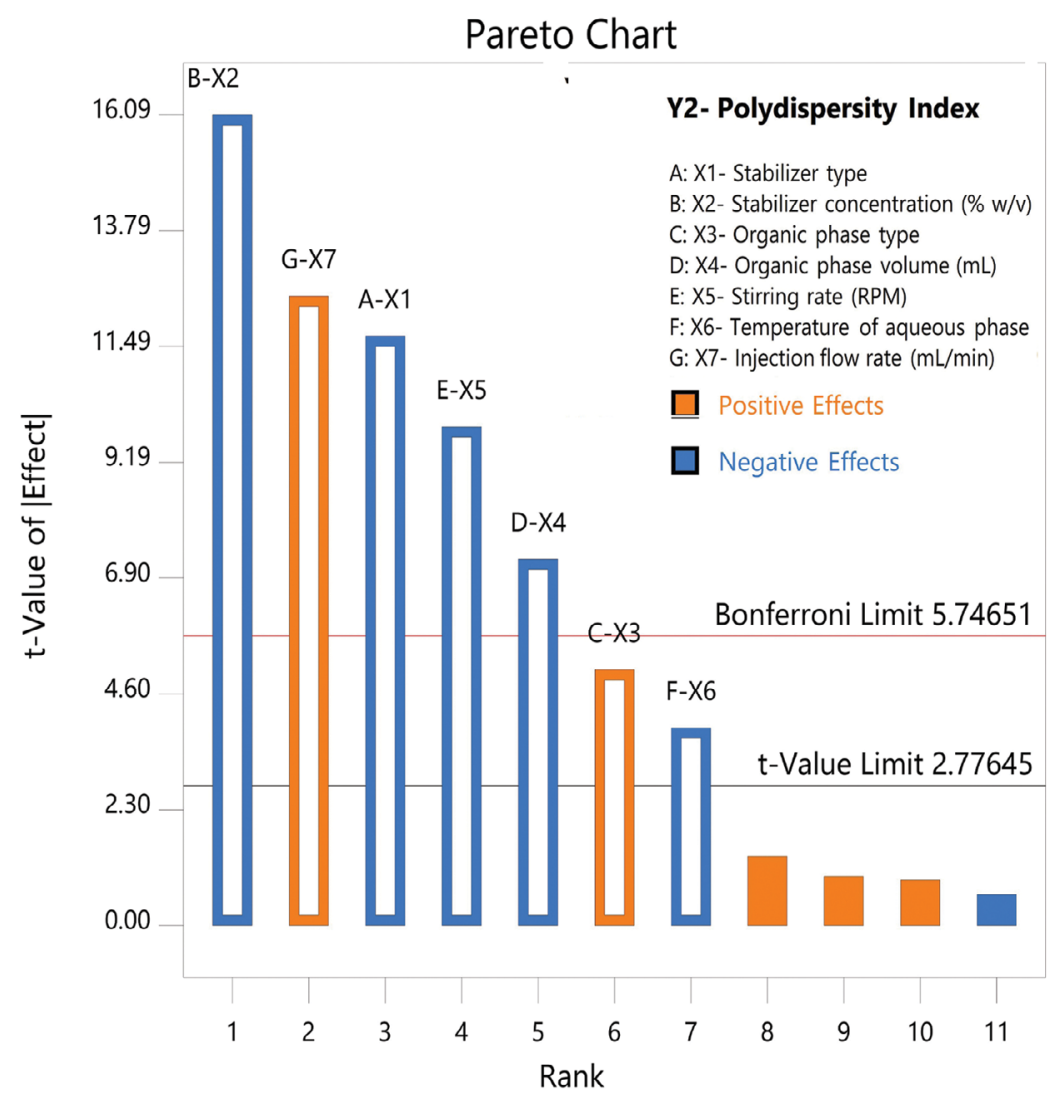

Figure 3. Pareto chart for Polydispersity index $\left(\mathrm{Y}_{2}\right)$. 
tion. ${ }^{17}$ The increase in stirring rate effects in particle size reduction since the intensification of micromixing. Higher micromixing efficacy improved the rate of diffusion and the mass transfer between the multiphase, imparts greater homogenous supersaturation in a very short time and thus to rapid and uniform nucleation, producing smaller drug particles with narrow size distribution. ${ }^{20}$

The stabilizer type, TPGS-1000 significantly reduces the PDI compared to that of Pluronic P85. The organic phase type, acetone favours the smaller particle size compared to that of methanol. This may be due to changes in the solvent type not only alters the supersaturation during evaporation phases but also affects viscosity and surface tension, which also changes the nucleation rate. ${ }^{16}$ Additionally, the results show that higher volume of organic phase $(12 \mathrm{~mL})$ marginally (\% contribution is 7.07) favours reduced PDI, maybe because it further decreases the drug concentration in organic phase and thus prevents uneven particle growth. The temperature of aqueous phase $\left(\mathrm{X}_{6}\right)$ was found to have the least effect on PDI with a negative coefficient. The 'factors' responsible for the major variability were affirmed as the active or influential variables, while others were termed as noise variables.

\section{Scanning electron microscopy}

The surface morphology of PTV (unprocessed drug) and PTV nanoparticles (PNS10) are presented in Fig. 5. PTV

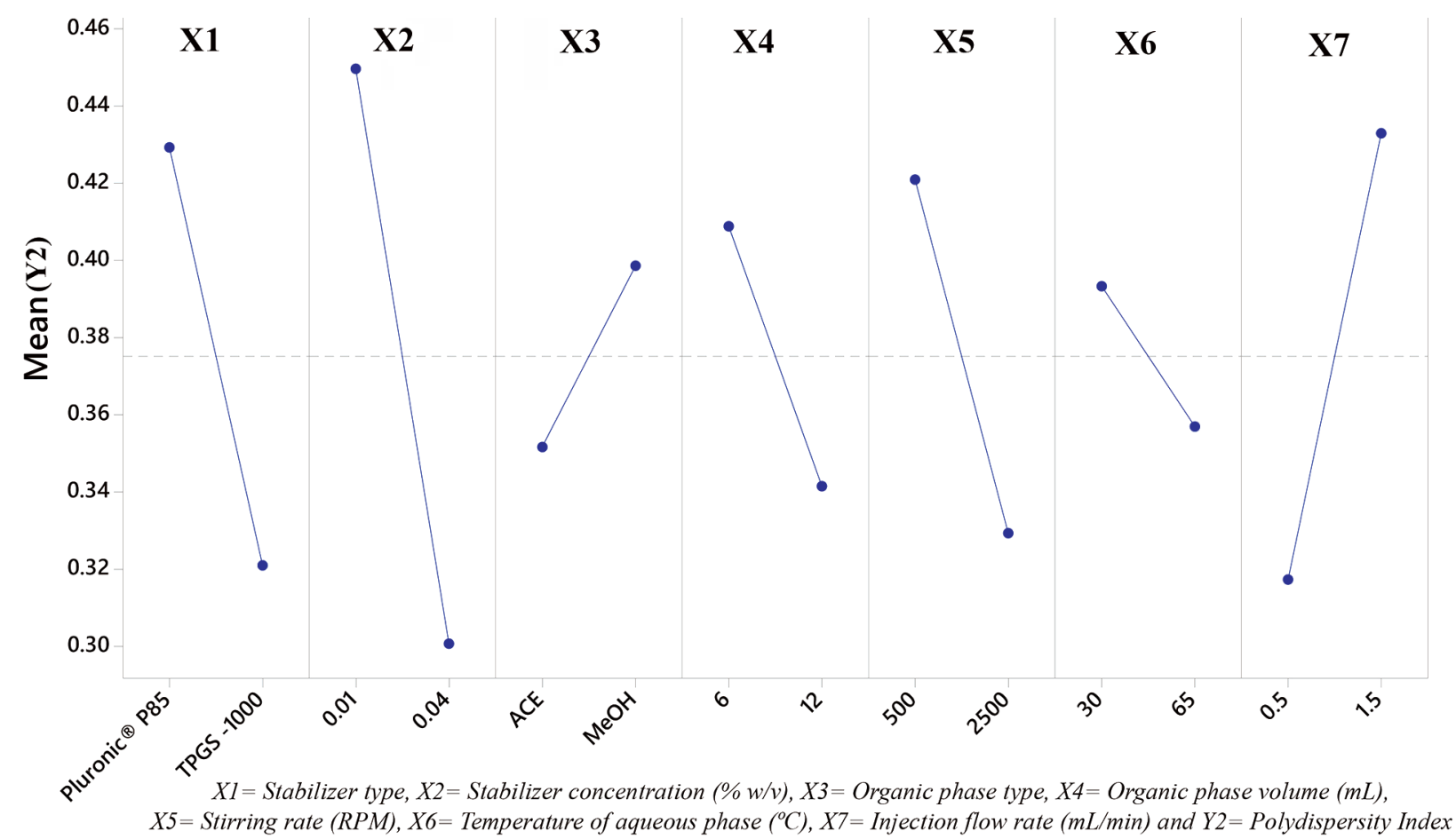

Figure 4. Term effect plot for polydispersity index $\left(\mathrm{Y}_{2}\right)$.
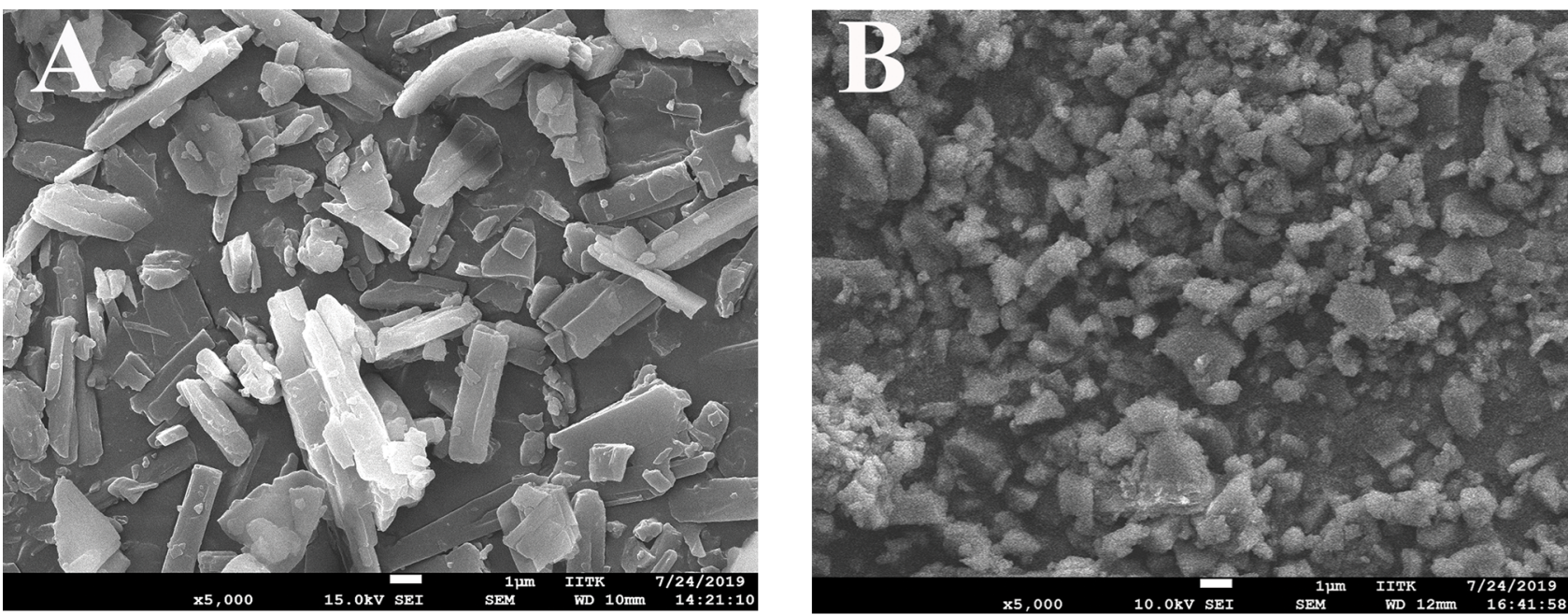

Figure 5. SEM image of A) PTV unprocessed and B) PTV nanoparticles. 
(Fig. 5A) appeared as crystalline, almost needle-shaped morphology, whereas PTV nanoparticles (Fig. 5B) show a substantial change in shape and surface morphology.

\section{Powder X-ray diffraction study}

The X-ray diffraction (XRD) scan of unprocessed PTV showed intense peaks of crystallinity, whereas PTV nanoparticle exhibited a halo pattern with less intense and denser peaks compared to unprocessed PTV (Fig. 6). This pattern indicates the decrease in crystallinity and amorphization of the drug in its nano form.

\section{CONCLUSIONS}

In the present study, various process and formulation variables were successfully evaluated and screened using Placket-Burman design. The stabilizer concentration, stirring rate, and injection flow rate were the most critical factors which affect the particle size and polydispersity index of nanoparticle formulation. Additionally, less influential factors like stabilizer type (TPGS-1000), organic phase type (acetone), organic phase volume $(12 \mathrm{~mL})$, and temperature $\left(65^{\circ} \mathrm{C}\right)$ were set at a favourable level. SEM study reviled the substantial change in shape and surface morphology
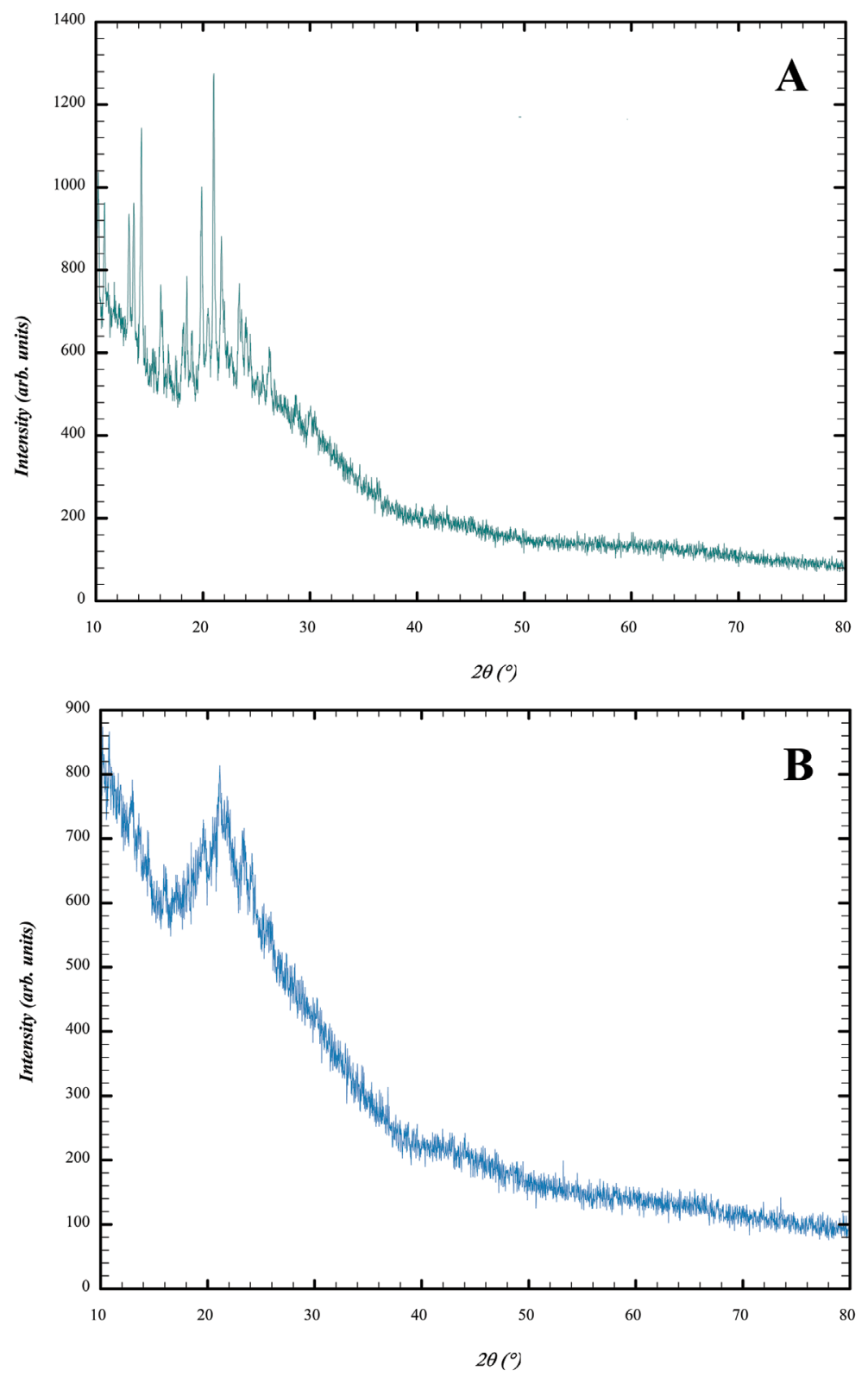

Figure 6. XRD plot of A) PTV unprocessed and B) PTV nanoparticles. 
of PTV after formulated into nanoparticles. Moreover, the XRD study confirmed the amorphous nature of nanoparticles. These results indicate the effective application of the emulsion solvent evaporation technique in the preparation of nanoparticles. The subsequent experimentation can be performed using these critical parameters to understand and analyze the nature of interactions among them using response surface methods.

\section{Acknowledgements}

The authors would like to thank Dr. Vijay B. Sutaria, Dr. M. C. Gohel, Dr. R. H. Parikh, Dr. Mihir Raval and Dr. Vineet C. Jain for providing essential technical assistance.

\section{REFERENCES}

1. Hawley CE, Roefaro J, Forman DE, et al. Statins for primary prevention in those aged 70 years and older: a critical review of recent cholesterol guidelines. Drugs Aging 2019; 36(8):687-99.

2. Singh S, Zieman S, Go AS, et al. Statins for primary prevention in older adults - moving toward evidence-based decision-making. J Am Geriatr Soc 2018; 66(11):2188-96.

3. Suades R, Padró T, Crespo J, et al. Liquid biopsy of extracellular microvesicles predicts future major ischemic events in genetically characterized familial hypercholesterolemia patients. Arterioscler Thromb Vasc Biol 2019; 39(6):1172-81.

4. Grundy SM. Primary prevention of cardiovascular disease with statins: Assessing the evidence base behind clinical guidance. Clin Pharm 2019; 10. doi.org/10.1211/CP.2016.20200568.

5. Alfirevic A, Neely D, Armitage J, et al. Phenotype standardization for statin-induced myotoxicity. Clin Pharmacol Ther 2014; 96(4):470-6.

6. USFDA Cfdear. Non-Clinical Review: NDA 208379 (Class 2 Resubmission) Pitavastatin Magnesium. 2015. 20-12-2019. 2083790 rig15000.

7. Saffie-Siebert R, Ogden J, Parry-Billings M. Nanotechnology approaches to solving the problems of poorly water-soluble drugs. Drug Discovery World 2005; 6(4):71-5.

8. Nirmala D, Chakradhar PA, Sudhakar M. Preparation and characterization of Pitavastatin solid dispersions. Res J Pharm Technol 2016; 9(5):555-8.
9. Van Der Schaaf PA, Blatter F, Szelagiewicz M, et al, inventors; Nissan Chemical Corp, assignee. Crystalline forms of pitavastatin calcium. USA patent US20180346425A1. 2018 Dec 6.

10. Ahmed TA, Bawazir AO, Omar AM, et al, inventors; King Abdulaziz University, assignee. Mucoadhesive buccal film having a dual release carrier system. US patent 10709662. 2020 July 14.

11. Mahalakshmi K. Formulation and in-vitro evaluation of Liquid and solid self microemulsifying Drug delivery system of pitavastatin Calcium [Masters Thesis], Chennai, Dr MGR Medical University 2018.

12. Goel S, Sachdeva M, Agarwal V. Nanosuspension technology: recent patents on drug delivery and their characterizations. Recent patents on drug delivery \& formulation 2019; 13(2):91-104.

13. Qiu L, Zhao X, Zu Y, et al. Ursolic acid nanoparticles for oral delivery prepared by emulsion solvent evaporation method: characterization, in vitro evaluation of radical scavenging activity and bioavailability. Artif Cells Nanomed Biotechnol 2019; 47(1):609-20.

14. Loh ZH, Samanta AK, Heng PWS. Overview of milling techniques for improving the solubility of poorly water-soluble drugs. Asian J Pharm Sci 2015; 10(4):255-74.

15. Ramasamy T, Tran TH, Choi JY, et al. Layer-by-layer coated lipidpolymer hybrid nanoparticles designed for use in anticancer drug delivery. Carbohydr Polym 2014; 102:653-61.

16. Kakran M, Sahoo NG, Tan I-L, et al. Preparation of nanoparticles of poorly water-soluble antioxidant curcumin by antisolvent precipitation methods. J Nanopart Res 2012; 14(3):757.

17. Kocbek P, Baumgartner S, Kristl J. Preparation and evaluation of nanosuspensions for enhancing the dissolution of poorly soluble drugs. Int J Pharm 2006; 312(1-2):179-86.

18. Guo Y, Luo J, Tan S, et al. The applications of Vitamin E TPGS in drug delivery. Eur J Pharm Sci 2013; 49(2):175-86.

19. Joye IJ, McClements DJ. Production of nanoparticles by anti-solvent precipitation for use in food systems. Trends Food Sci Technol 2013; 34(2):109-23.

20. Zhang J-Y, Shen Z-G, Zhong J, et al. Preparation of amorphous cefuroxime axetil nanoparticles by controlled nanoprecipitation method without surfactants. Int J Pharm 2006; 323(1-2):153-60.

21. Cushing BL, Kolesnichenko VL, O'Connor CJ. Recent advances in the liquid-phase syntheses of inorganic nanoparticles. Chem Rev 2004; 104(9):3893-946.

22. Langer K, Balthasar S, Vogel V, et al. Optimization of the preparation process for human serum albumin (HSA) nanoparticles. Int J Pharm 2003; 257(1-2):169-180.

23. Plackett RL, Burman JP. The design of optimum multifactorial experiments. Biometrika 1946; 33(4):305-25. 


\title{
Применение дизайна Plackett-Burman для скрининга фракторов, влияющих на разработку состава наночастиц питавастатина
}

\author{
Винодкумар Д. Рамани ${ }^{1}$, Гириш К. Джаниㄹ, Гириш У. Саилор 3 \\ ${ }^{1}$ Кафедра фармации, Технический университет Гуджарат, Ахмедабад, Индия \\ ${ }^{2}$ Кафедра фармачии, Фармацевтический колледж „, К.Б. Равал“, Гандинагар, Индия \\ ${ }^{3}$ Фармацевтический колледж „Багван Махавир“, Университет „Багван Махавир“, Сурат, Индия
}

Адрес для корреспонденции: Винодкумар Д. Рамани, Кафедра фармации, Технический университет Гуджарат, Ахмедабад, Индия; E-таil: vinod.ramani01@gmail.com

Дата получения: 1 сентября 2020 Дата приемки: 30 сентября $2020 \diamond$ Дата публикации: 31 октября 2021

Образец цитирования: Ramani VD, Jani GK, Sailor GU. Application of Plackett-Burman design for screening of factors affecting pitavastatin nanoparticle formulation development. Folia Med (Plovdiv) 2021;63(5):775-85. doi: 10.3897/folmed.63.e58174.

\section{Резюме}

Введение: Формула наночастиц кальция питавастатин является потенциальной альтернативой решению проблемы растворимости. Однако в формулу наночастиц входят различные параметры, влияющие на качество продукта. План PlackettBurman может поддержать экономический экспериментальный план, который фокусируется на определении относительной важности многих других.

Цель: Целью этого исследования было выявить переменные, которые могут существенно повлиять на формулу наночастиц питавастатина.

Материалы и методы: Формула наночастиц пивастатина была получена наносуспензией с использованием метода испарения эмульсии растворителя с последующей лиофилизацией. Была применена методология скрининга дизайна PlackettBurman, в которой семь двухуровневых факторов были изучены в 12 экспериментах для изучения влияния формулы и переменных процесса на размер частиц и индекс полидисперсности наночастиц. Также оценивали морфологию поверхности и кристаллическую природу частиц.

Результаты: Размер частиц и индекс полидисперсности находились в диапазоне от 113.1 до $768.5 \mathrm{~nm}$ и от 0.068 до 0.508 соответственно. Статистический анализ различных переменных показал, что концентрация стабилизатора, скорость введения и скорость перемешивания были наиболее влиятельными факторами, влияющими на размер частиц и индекс полидисперсности формулы. Исследования дифракции рентгеновских лучей (ДРЛ) и сканирующая электронная микроскопия (СЭМ) доказали аморфную природу наночастиц.

Заключение: В исследовании сделан вывод о том, что план Plackett-Burman является эффективным инструментом для скрининга переменных процесса и формулы, влияющих на свойства наночастиц питавастатина, а также для определения наиболее важного фактора.

\section{Ключевые слова}

сублимационная сушка, наночастицы, питавастатин, дизайн Plackett-Burman, дизайн скрининга 